\title{
Risks and benefits of the practice of anesthesiology
} Peter G. Duncan MD FRCPC

\section{Lecture Objectives}

To review the occupational hazards of a career in anesthesia, and to refocus on the continued benefits of working within this specialty.

Few can deny that these are uncomfortable times to be in medical practice, and the pace of change is affecting all physicians. ${ }^{1}$ It is disquieting that many within the specialty are presenting a negative image of a career in anesthesia, for such pessimism is affecting others currently in practice, or those contemplating entering training. The practice of anesthesia has both risks and benefits to the practitioner; by minimizing the former and accentuating the latter our enjoyment of the specialty should improve dramatically.

\section{The risks of anesthesia practice}

\section{$A$ Life expectancy of anesthesiologists}

There has been considerable speculation over the years about the effect of the OR environment on the life expectancy of those of us who work there. In 1968, a retrospective survey of the cause of death among American anesthesiologists found that the death rate was less than that of the general male population, as was the death rate from all forms of cancer. However, there was a statistically significant increase in the incidence of cancer of the lymphoid and reticuloendothelial systems. A second prospective study ${ }^{2}$ could not confirm this increased incidence of cancer, while a third study ${ }^{3}$ also found no evidence for an increased death rate due to cancer, hepatic disease, or renal disease.

The theoretical basis upon which the anesthetic environment is speculated to be carcinogenic includes the contamination with trace amounts of anesthetic drugs. However, there has been no reported evidence of an increased incidence of cancer when animals have been exposed to low concentrations of anesthetics for a prolonged period of time. In addition, a mutagenic effect has not been observed when inhalation anesthetics have been studied in common in vitro tests for carcinogens. Nevertheless, risk reduction by scavenging of any foreign material and expired gases is both practical and logical.
Death-in-post and early retirement due to ill health has been found to be increased significantly in consultant anesthetists in England, in contrast to control consultants in five other medical specialties. ${ }^{4}$ Unfortunately, the data were confidential, and we have no idea about the causes of death or the nature of the ill health leading to the early retirements.

Suicide is one outcome reported to be more common in the medical profession, and in anesthesiologists in particular. ${ }^{3}$ A more recent study in the UK found no increased risk in anesthetists, but confirmed the increased risk for doctors as a group compared with the general population. ${ }^{5}$ Age was not a risk factor per se, but great concern was expressed over the number of suicides among trainees in anesthesia. This was probably a function of the growing problem of drug addiction among this group.

\section{$B$ Reproductive bazards}

Several years ago, epidemiological studies raised concern that exposure to trace concentrations of anesthetic gases was related to an increased risk of spontaneous abortion and potential congenital birth defects. While most of the studies could be criticized for their design and comparison groups, the most compelling evidence for risk came from dental operators. In a large retrospective questionnaire of dentists and dental assistants, ${ }^{6}$ it was suggested that people who work in offices where nitrous oxide was used had a higher incidence of health problems than those working in offices where $\mathrm{N}_{2} \mathrm{O}$ was not used. Women in the exposed offices had an incidence of spontaneous abortion 2.3 times that of the control group. Another questionnaire survey ${ }^{7}$ suggested that dental assistants exposed to nitrous oxide had reduced fertility.

However, these questionnaire surveys are very prone to responder bias. In addition, it has been shown that the increased risk of abortion is not limited to those who deliver anesthetics. In a Scandinavian survey $^{8}$ the abortion rate for scrub nurses was $21 \%$, for ICU nurses $17 \%$, and for anesthesia nurses $15 \%$. Finally, in a more objective study using the computerized records of the Swedish Health Registry ${ }^{9}$ to review

Department of Anaesthesia, Capital Health Region, Victoria, BC 
the obstetric records of women who worked in the OR compared with women in other fields of medicine, there was no difference between the groups with regard to the incidence of threatened abortion, perinatal death rate, birth weight of offspring, or of congenital malformations.

Spence ${ }^{10}$ conducted a survey from 1977 to 1984 of all UK female medical school graduates aged $40 \mathrm{yr}$ or less and working within a hospital. They collected data on details of occupation, work practice, lifestyle, medical and obstetrical history, as well as some personal details. Of the 11,500 women surveyed, there was an $85-92 \%$ response rate. They found that female anesthesiologists did not have an increased risk of infertility, and there was no correlation between spontaneous abortion or development of congenital anomalies in live-born children and the occupation of the mother, hours exposed to the OR environment, or the use of scavenging apparatus. There was also no increase in the incidence of cancer or neuropathy.

We must conclude that the possibility of a miscarried pregnancy is the only potential significant medical problem for OR personnel, but even that risk is very low (less than that for smokers, or people working in $\mathrm{X}$-ray). The cause of the problem, if it does exist, is not obvious.

\section{$C$ Latex sensitization}

In recent years, the application of universal precautions to prevent transmission of infectious diseases has produced a new health concern - latex allergy. Sensitization of health care workers can lead to severe latex allergic reactions, including death from anaphylaxis (type-I reactions). The basic problem is that work exposure generates IgE immunoglobins to proteins found in natural rubber products; when later exposed to allergens as a patient the individual is at risk of a fatal reaction. More than 15 such fatalities had been reported to the FDA between 1988 and 1992. It has been estimated that working in the health care field raises the risk of sensitization from $8 \%$ in the general population to $20 \%$ !

It is important to note that airborne latex allergen accounts for $\mathbf{8 0 - 9 0 \% ~ o f ~ a l l ~ e x p o s u r e s ~ f o r ~ m o s t ~ h e a l t h ~}$ care workers, with the greatest load coming with the donning and removal of powdered gloves. ${ }^{11}$ The concentrations of allergen on gloves varies greatly, over 3,000 times among manufacturers. Even with the same product there can be a 40 -fold variation from lot-to-lot of the same brand. Other routes of exposure are many, including direct dermal contact, absorption through abraded skin, or mucocutaneous exposure. It has even been reported by indirect exposure in family members from contact with proteins from the health care workers surgical scrubs!

The individuals at greatest risk are those with a history of atopy or hand dermatitis, and frequent use of disposable gloves. A prevalence study conducted in Toronto physicians ${ }^{12}$ and recently confirmed in the USA $^{13}$ showed a history of glove symptoms did not reliably indicate latex allergy by skin test.

Conversely, absence of glove symptoms does not rule out sensitization! The symptoms of sensitization are non- specific, and resemble those of an upper respiratory infection (tearing, redness, puffy eyes, nasal congestion, sneezing, wheezing, etc.), GI distress, or a non-specific rash, pruritus, or burning of the hands. The only clue may be a temporal relationship to working hours.

The logical risk reduction strategy is to STOP THE SENSITIZATION! Everyone in the OR should use non- powdered, low-allergen latex gloves, synthetic gloves, or vinyl gloves. In addition, since intact skin is an effective barrier, use water-based skin lotions and cover cuts and open sores with a plastic dressing.

\section{Infectious diseases}

The first line of defense against infection is the routine use of protective barriers including gloves, gowns, and eye wear. When gloves are contaminated they must be removed before touching other patients, anesthetic equipment, syringes, or other articles (such as one's pen to complete the chart!). Unfortunately, universal precautions are not universally applied. In one anesthetic study ${ }^{14}$ compliance with gloving policy for induction was only $55 \%$ overall, and only $11 \%$ for faculty over the age of $55 \mathrm{yr}$.

Contamination of the skin with blood occurs in $18 \%$ of peripheral venous insertions, $87 \%$ of central lines, and $38 \%$ of insertion of arterial lines. Gloving can reduce $98 \%$ of the contamination. Since penetrating injuries, particularly with hollow needles, are the most dangerous for disease transmission, it is worthwhile knowing that the incidence of needlesticks does not increase with the use of gloves. ${ }^{15}$ In a multicentre, prospective study of percutaneous injuries in anesthesia personnel ${ }^{16} 87 \%$ of injuries were from hollow bore needles, $43 \%$ were moderate or deep, and $68 \%$ of them were preventable with improved techniques.

\section{Human ImMUNODEFICIENCY VIRUS (HIV) PREVENTION}

While receiving the greatest press, the estimated risk of HIV infection after percutaneous exposure to blood or body fluids is only $0.3 \%$. Risk factors for seroconversion rate include deep injury, visible conta- 
mination with the source patient's blood, procedures in which the contaminating device was placed inside the source patient's vein or artery, and terminal illness in the source patient. ${ }^{17}$

While the chance of infection after a single exposure may be slight, the prevalence of the disease in the population $(0.3 \%$ of all subjects in the USA, but much increased in trauma patients), the inevitability of accidental needlesticks, and the length of time in practice, a young anesthesiologist may have as high as a 1 in 25 chance of contracting AIDS over a 40 year career!

The risk management of post-exposure subjects has been recently changed in the UK, Canada, ${ }^{18}$ and the USA. In essence, it is now desirable to begin triple chemoprophylaxis immediately (within 1-2 hours, if possible) in high-risk exposures. The regimen may not be effective if withheld $24-36 \mathrm{hr}$ post-exposure. ${ }^{17}$

\section{il Hepatitis B Virus contamination}

In contrast to the low seroconversion after HIV exposure, the risk of $\mathrm{HBV}$ infection after a hepatitis B eantigen positive needlestick injury is $37 \%$. The prevalence of the virus in the surgical population is also greater than HIV, ranging from 0.2 to $1.5 \%$. The HBV seroprevalence correlates best with the frequency of blood contact; the frequency of needle accidents has an independent but lesser effect. Risk reduction occurs through immunization with hepatitis $B$ vaccine.

\section{iII Hepatitis C Virus exposure}

The risk of $\mathrm{HCV}$ infection after an HCV blood-contaminated needlestick injury is about $2 \%$; this rate has been established in epidemiological follow-up after occupational injury related to dialysis therapy. Unfortunately, not all patients with hepatitis $\mathrm{C}$ become antibody positive, so the test is not useful for establishing carrier status or chronic infection.

There is no vaccine against $\mathrm{HCV}$; the only prevention relates to universal blood precautions. Immune globulin prophylaxis is no longer recommended after a percutaneous exposure to $\mathrm{HCV}$.

\section{Multiple-Drug-Resistant Tuberculosis}

The number of new cases of TB has been steadily increasing in North America since 1985, as has the prevalence of drug resistance: it is now estimated that $33 \%$ of new cases in New York City are resistant to isoniazid. Since tuberculosis is transmitted through the air by droplet nuclei, anesthesiologists are at risk for infection from patients with active pulmonary disease. ${ }^{19}$

As to prevention of occupational exposure it is important to note that common OR masks are not effective at filtering the infective organism and leave too many face-seal leaks; special high-efficiency masks with greater filtering capability or personal respirators without leaks may be necessary. Routine surveillance of health care workers by annual skin testing is also recommended. BCG vaccination has not been shown to be cost effective compared to regular tuberculin testing and preventative therapy.

\section{E Stress-related illness}

Occupational stress has been defined as "a negatively perceived quality, which, as a result of inadequate coping with sources of stress, has negative mental or physical health consequences". ${ }^{20}$ Stress arises from the interaction of the individual with their environment and occurs when there is a perceived imbalance between the demands made on the individual and their ability to meet that demand. While stress is an inevitable concomitant of both personal and professional life, and moderate levels provide the driving force for us to function properly, it is when it gets out of control that problems begin.

The Association of Anaesthetists of Britain and Ireland conducted an interactive session in September 1995 and defined, to some extent, the scope of the problem. They found that the principle sources of stress in anesthetic practice were lack of control ( $42 \%$ of respondents), administrative responsibilities (41\%), and conflicts between the demands of work and home (35\%).

Stress is not unique to anesthesiologists; in the 1998 CMA survey of Canadian physicians the majority reported feelings of frustration and fatigue. ${ }^{21}$ The unique complaint of anesthesiologists is the inability to organize their own professional lives. ${ }^{22}$ Once they reach their $40 \mathrm{~s}$ and 50 s most professionals expect to plan and control their own working pattern, and our inability to do so may prove increasingly stressful.

A recent USA study of aging and stress in anesthetic practice ${ }^{23}$ showed that all ages found night call very stressful, and reported as the most common factor leading to retirement. While younger physicians found economic uncertainty, production pressure, and interpersonal relations weare more stressful than older age groups, the 40-49 yr age group rated liability concerns as more stressful.

The issue of sleep deprivation and fatigue on the performance of physicians in general, and anesthesiologists in particular, has received special attention. ${ }^{24}$ This factor has focused more on residents, and a recent national survey of American anesthesiology residents ${ }^{25}$ showed a pattern of sleep insufficient to sustain optimal function. This may be a factor in the twice-normal incidence of automobile accidents involving anesthesia residents after on-call duty cycles. ${ }^{26}$ 


\section{PSYCHOLOGICAL ILLNESS}

Depression, disillusionment and dissatisfaction within medicine are widespread, and there is little evidence that it is more marked in anesthesiologists than in other doctors in hospital, community, or general practice. In May, 1998, the Medical Post quoted the registrar of the BC College of Physicians and Surgeons as saying that " $10 \%$ of the province's doctors were being monitored for stress-related disability!" Concern for stress-related illness has led to a new psychiatric entity ("wounded care-giver"), and has led the CMA to publish a policy summary on physician health and well-being. ${ }^{27}$

As to anesthesia, most of the published studies are extremely dated, and apply little to modern practice. A 1988 survey in Canada of senior staff anesthesiologists ${ }^{28}$ in Alberta and Ontario showed they were very satisfied with their work; the least satisfied were, on average, seven years younger than the satisfied group. The study group was characterized as "intelligent, somewhat dominant yet sensitive, independent yet somewhat unsure and rather tense. They were also tolerant, shy, and rather serious. Women in the specialty were more tender-hearted, sensitive, and overprotective." Unfortunately, we do not have parallel information about other specialties!

A recent USA survey ${ }^{29}$ correlated work stress in anesthesiologists with the number of hours in the $O R$. In addition, highly stressed individuals were more likely to report depression, fatigue, anger and irritability, and headaches and hostility. Once again, there was no "control" group of physicians from other specialties with which to compare the results in our specialty.

Alcohol abuse is reputedly more common in physicians than in other groups, but evidence to support the impression is difficult to find. Anesthesiologists do not seem to be uniquely at risk.

Illicit drug use (marijuana and cocaine) was more common in Canadian interns and residents than in a general population. However, when compared with age-matched controls, there was no difference; the findings simply reflected the social mores of a particular age group. Unfortunately, trainees in anesthesiology and psychiatry were more common users than those in other specialties. A survey of one large American school ${ }^{30}$ showed no difference in the use of psychoactive substances by graduates of Internal Medicine (19.9\%), Surgery (14.4\%), or Anesthesia (16.8\%).

\section{Chemical Dependency}

It is now apparent that chemical substance abuse is an occupational disease of major importance to anesthesiologists. ${ }^{31}$ Based on the data from the ASA substance abuse survey, the incidence rate for new substance abuse (across all drugs) in the 1994-5 training year was $0.4 \%$ for residents, and $0.1 \%$ for attending staff. The specific rate for fentanyl abuse among residents was $0.25 \%$ for this training year. This actually represented a decline over the $10 \mathrm{yr}$ that the survey was conducted. The same survey found a relapse rate when physicians returned to anesthesiology of $19 \%(6 / 31)$ in residents and $5 \%(1 / 20)$ in attending staff.

Chemical dependence in physicians is a disease of loneliness, despair, increasing guilt and fear. It is not a "social" addiction that is the norm with marijuana, cocaine, or other drugs abused by those in other walks of life. Anesthesiologists make up only $4 \%$ of physicians, yet up to $30 \%$ of physicians in drug treatment programs; whether this is a detection phenomenon or a true incidence difference cannot be known. Contributing factors include job stress, isolation, lack of recognition, and lack of self respect. Of course, the possibility that the specialty attracts those with a susceptible personality, combined with daily access to substances, is always a factor.

III RISK REDUCTION OF STRESS-RELATED DISEASE Stress reduction requires first that we recognize that it occurs, in both ourselves and others, and that we need to address causative factors in our daily lives in an open fashion. Individually, it is important that we simplify our existence to our own manageable level: limit the number of things we own, become involved with, or commit to complete. Success achieved at the expense of enjoyment of life is no success at all!

Anesthesiologists have to be taught to manage stressors effectively, and to learn the important skills of communication, assertiveness, conflict management and time management. By becoming involved and knowledgeable in the processes within our hospitals physicians will find them less frustrating as change occurs. Finally, we need to avoid irrational thinking: for example, proceeding to provide an anesthetic against one's better judgment because of pressure from the surgeon.

\section{The benefits of anesthesiology}

\section{A Job opportunities}

Recent years have seen dramatic changes in the way medical care is delivered, and how it is reimbursed. As a specialty we have taken a conservative view with respect to staffing, leaving positions vacant rather than risking having too many mouths to feed from a diminished workload. This has left the impression that there are no jobs out there for graduates, and one should avoid enrolling in anesthesiology training. 
An analysis of the Canadian situation from the 1996 CARMS match does not suggest that Canadian medical school graduates even consider the job market, income potential, or prestige within the medical profession when they choose a career. The reasons that anesthesiology was chosen were: doing a clerkship in the specialty $(84 \%)$, interest in the unique practice of the specialty $(78 \%)$, and role models in the field $(75 \%)$. The role modeling of community anesthesiologists, observed while students are on other rotations, was particularly notable. An earlier 1993 survey suggested the attraction of anesthesiology as "hands-on", “Time-off', "Physiology / Pharmacology", and "Immediate gratification". ${ }^{32}$ It is clear that, if we want recruitment, students should be isolated from those who decry the woes of the specialty!

In reality, there promises to be no shortage of jobs in Canada. The reduction in resident numbers imposed by regulatory governments, combined with impediments to immigration and expanded roles in perioperative medicine, will leave us short of practitioners for years to come.

\section{$B$ Quality of life}

Many of us acknowledge the fact that anesthesiology practice has the potential to provide some of the best qualities of personal life in conjunction with a professional career. The regular hours of work, predictable duty roster, unlimited opportunities for job-sharing or reduced practice, and opportunity to pursue outside interests attract many candidates to the specialty. Indeed, these "outside interests" make anesthesiologists the interesting role models of a balanced medical career.

A further benefit follows from the basic accountability of anesthesiology: rather than being "on call" directly to the patient as occurs in a primary care field, anesthesiologists respond to the needs of our medical institutions. The calls are always genuine, and occur on a scheduled basis; when "off-call", anesthesiologists are seldom required to respond. Few if any specialties possess such an advantage!

\section{Quality of practice}

All repetitive duties become monotonous over time; anesthetic practice is no different. However, anesthesiology is one of the "horizontal" facilitating specialties that bring us into contact with patients of virtually all other physicians. Whether it is in the OR, the ICU, $\mathrm{X}$-ray department, clinic, or labour floor we participate in the full scope of medical service. There are very few other practices which share this advantage; most others are vertically organized to limit their patient contact by either patient characteristics (pediatrics, obstetrics, etc.) or by organ system (ophthalmology, orthopedics, urology, etc.). As long as we remain connected with the mainstream of patient volume and the broadest scope of disease, we will remain stimulated by medical progress and satisfied with our facilitating service role.

\section{Financial reward}

The unfortunate part of recent health care reform has been the financial impact upon individual practitioners. Before 1993 anesthesiology departments used to be major money-makers for hospitals and medical schools, and the rewards to providers were rising progressively. However, since that time, with managed care in the USA and hospital reform in Canada, the tables have turned. The institutions have learned that "the cheapest care is no care" but, when care must be provided, it should be provided at the cheapest cost. In essence, anesthesiology moved from being an asset to representing a cost liability in a remarkably short time!

In the USA, the Medical Group Management Association tracks financial data of various specialties. The basis for anesthesiology figures is from 1,347 anesthesiologists in private practice, and a further 1,183 working in academic settings. Income is measured by median gross compensation for 1997, as reported in 1998:

\section{Median gross compensation for 1997 (USA)}

$\begin{array}{lll}\text { Specialty } & \begin{array}{l}\text { Private Sector } \\ \text { Physicians }\end{array} & \begin{array}{l}\text { Academic } \\ \text { Faculty }\end{array} \\ \text { Anesthesiology } & \$ 237,390 & \$ 170,000 \\ \text { Family Practice } & \$ 132,434 & \$ 120,000 \\ \text { Internal Medicine } & \$ 140,000 & \$ 112,972 \\ \text { Pediatrics } & \$ 132,039 & \$ 105,846 \\ \text { Emergency Medicine } & \$ 179,997 & \$ 148,737 \\ \text { Surgery: General } & \$ 223,388 & \$ 198,135 \\ \text { Surgery: Orthopedic } & \$ 310,475 & \$ 246,113\end{array}$

In Canada, we do not have the same need to negotiate physician contracts, so our data runs a bit late. However, the CMA does utilize data from the Canadian Institute for Health Information (CIHI), based upon billing data from provincial medical care plans, to determine the average gross fee-for-service payment per physician. These are corrected to averages for a full-time-equivalent, and are presented broadly by specialty. ${ }^{33}$ The gross billings can then be corrected for estimated overhead \%'s as determined by the CMA from survey information. 


\section{Average FFS payments per full-time equivalent $\mathrm{MD}$ (Canada)}

\begin{tabular}{|c|c|c|c|}
\hline Group & $\begin{array}{l}\text { 1993-94 } \\
\text { Average Gross }\end{array}$ & Overbead \% & $\begin{array}{l}\text { Estimated } \\
\text { Net(before tax }\end{array}$ \\
\hline $\begin{array}{l}\text { Anesthesia } \\
\text { Family }\end{array}$ & $\$ 172,353$ & $17 \%$ & $\$ 143,053$ \\
\hline $\begin{array}{l}\text { practice } \\
\text { Medical }\end{array}$ & $\$ 157,044$ & $39 \%$ & $\$ 95,483$ \\
\hline $\begin{array}{l}\text { Specialists } \\
\text { Surgical }\end{array}$ & $\$ 170,915$ & $29 \%$ & $\$ 121,521$ \\
\hline $\begin{array}{l}\text { Specialists } \\
\text { All Physicians }\end{array}$ & $\begin{array}{l}\$ 228,673 \\
\$ 173,095\end{array}$ & $\begin{array}{l}36 \% \\
36 \%\end{array}$ & $\begin{array}{l}\$ 144,979 \\
\$ 110,608\end{array}$ \\
\hline
\end{tabular}

It is again noted that the CIHI (medicare) figures are independent of compensation paid by salary, capitation, sessional, or some other blend of remuneration. The CMA process of relating the $\$ \$$ to an FTE attempts to compensate for this oversight that would otherwise deflate the figures for specialties where this form of payment is common.

While specialists continue to earn higher salaries than their primary care counterparts, they are also working harder. If salaries are declining due to restraint, restructuring, or clawbacks, people will work harder and smarter. Anesthesiologists have difficulty doing so independent of the rest of the OR, leaving little ability to compensate for the changing system of health care funding. Their only option is to understaff their departments, and independently put in more hours to maintain personal income. While under-staffing in the early 1990 s seemed appropriate, the results of the CAS survey show that most anesthesiologists in Canada have more than enough to do, and the present service loads are contributing to our current unrest.

\section{Conclusion}

Anesthesiologists (and other physicians) may perceive themselves as victims of the recent re-engineering of medical services, for they are now valued only as a "service industry" contributing to the smooth functioning of our medical care facilities. The transition from individual physician to "program member" has already begun, and we have been rewarded with expanded roles in the form of initiatives such as perioperative medicine and ambulatory care. The examination of outcomes and effectiveness of care is leading to consideration of anesthesiologists (and other MDs) as part of a process or program rather than a discrete department or individual practitioners. It may not be the role we envisioned when we chose our career path, but we will be a respected and necessary contributor to the process of health care in the future.

On balance, an examination of the risks and benefits of a career in anesthesiology gives reason for optimism. The physical and psychological risks we endure can be easily reduced by simple measures; the benefits can be profound. Unfortunately, these are changing times, and change invariably leads to insecurity. However, since man is affected "not by things, but by his perception of things", it is time we began to look on the bright side of this specialty!

\section{References}

1 Modell $J H$. Health care delivery systems, managed care, and the changing practice of medicine. J Clin Anesth 1998; 10: 347-52.

2 Bruce DL, Eide KA, Smith NJ, et al. A prospective survey of anesthesiologist mortality 1967-71.

Anesthesiology 1974; 41: 71-4.

3 Lew EA. Mortality experience among anesthesiologists 1954-76. Anesthesiology 1979; 51 : 195-9.

4 McNamee R, Keen RI, Corkill CM. Morbidity and early retirement among anaesthetists and other specialists. Anaesthesia 1987; 42: 133-40.

5 Neil HAW, Fairer JG, Coleman MP, et al. Mortality among male anesthetists in the United Kingdom 1957. 83. BMJ 1987; 295: 360-2.

6 Cohen EN, Brown BW, Wu ML. Occupational disease in dentistry and chronic exposure to trace anesthetic gases. JADA 1980; 101: 21-31.

7 Rowland AS, Baird DD, Weinberg CR, et al. Reduced fertility among women employed as dental assistants exposed to high levels of nitrous oxide. N Engl J Med 1992; 327: 993-7.

8 Rosenberg $P$, Kirves $A$. Miscarriages among operating theatre staff. Acta Anaesthesio Scand 1973; 53(Suppl): $37-42$.

9 Erickson $H A$, Kallen $B$. Hospitalization for miscarriage and delivery outcome among Swedish nurses in operating rooms. Anesth AnaIg 1985; 64: 981-8.

10 Maran NJ, Knill-Jones RP, Spence AA. Infertility among female hospital doctors in the UK. Br J Anaesth 1996; 76: 581P.

11 Heilman $D K$, Jones $R T$, Swanson $M C$, et al. A prospective controlled study showing that rubber gloves are the major contributor to latex aeroallergen levels in the operating room. J Allergy Clin Immunol 1996; 98: 325-30.

12 Arellano R, Bradley J, Sussman G. Prevalence of latex sensitization among hospital physicians occupationally exposed to latex gloves. Anesthesiology 1992; 77: 905-8.

13 Brown RH, Schauble JF, Hamilton RG. Prevalence of latex allergy among anesthesiologists. Anesthesiology 1998; 89: 292-9. 
14 Ben-David B, Gaitini L. Compliance with gloving in anesthesia: an observational study of gloving practice at induction of general anesthesia. J Clin Anesth 1997; 9: 527-31.

15 Ben-David B, Gaitini $L$. The routine wearing of gloves: impact on the frequency of needlestick and percutaneous injury and on surface contamination in the operating room. Anesth Analg 1996; 83: 623-8.

16 Greene ES, Berry AJ, Arnold WP, et al. Percutaneous injuries in anesthesia personnel. Anesth Analg 1996; 83: 273-8.

17 Cardo DM, et al. A case-control study of HIV seroconversion in health care workers after percutaneous exposure. N Engl J Med 1997; 337: 1485-90.

18 Rachlis $A R$, et al. Guidelines for antiretroviral therapy for HIV infection. CMAJ 1998; 158: 496-505.

19 Tait $A R$. Occupational transmission to tuberculosis: implications for anesthesiologists. Anesth Analg 1997; 85: 444-51.

20 Dickson DE. Stress. Anaesthesia 1996; 51: 523-4.

21 Sullivan P, Buske L. Results from CMA's huge 1998 physician survey point to a dispirited profession. CMAJ 1998; 159: 525-8.

22 Seeley $H F$. The practice of anaesthesia - a stressor for the middle-aged? Anaesthesia 1996; 51: 571-4.

23 Travis $K W$, Mibevc NT, Orkin FK. Aging and the stress of anesthetic practice. Anesth Analg 1997; 84: S217.

24 Parker JBR. The effects of fatigue on physician performance - an underestimated cause of physician impairment and increased patient risk. Can J Anaesth 1987; 34: 489-95.

25 Howard SK, Healzer JK, Gaba DM. Sleep and work schedules of anesthesia residents: a national survey. Anesthesiology 1997; 87: A933.

26 Geer $R T$, Jobes $D R, T e w ~ J D$, et al. Incidence of automobile accidents involving anesthesia residents after on call duty cycles. Anesthesiology 1997; 87: A938.

27 Canadian Medical Association: Physician Health and well-being. CMAJ 1998; 158: 1191-5.

28 Clarke IMC, Morin JE, Warnell GH. Personality factors and the practice of anaesthesia: a psychometric evaluation. Can J Anaesth 1994; 41: 393-7.

29 Panagopoulos $G$. Work stress and distress among anesthesiologists: what are we at risk for? Anesthesiology 1998; 89: A1343.

30 Lutsky I, Hopwood K, Abram SE, et al. Use of psychoactive substances in three medical specialties: anaesthesia, medicine, and surgery. Can J Anaesth 1994; 41: 561-7.

31 Silverstein JH, Silva DA, Iberti T7. Opioid addiction in anesthesiology. Anesthesiology 1993; 79: 354-75.

32 Yang $H$, et al. Recruitment into anaesthesia: results of two national surveys. Can J Anaesth 1994; 41: 621-7.
33 Buske L. Physician's Gross Billings: the latest data. CMAJ 1998; 158: 1408. 


\section{Avantages et incon- vénients de la pratique de l'anesthésiologie}

Peter G. Duncan MD FRCPC

\begin{abstract}
Objectifs de la conférence
Passer en revue les risques du métier d'anesthésiologiste, et fixer l'attention sur les avantages de cette spécialité.

On ne peut nier que les temps sont difficiles pour la pratique médicale et que tous les médecins sont affectés par les bouleversements. ${ }^{1}$ Il est inquiétant de constater que nombre de praticiens de notre spécialité présentent une image négative de la carrière en anesthésie, ce pessimisme nuit à ceux qui sont actuellement en pratique ou à ceux qui songent à s'inscrire à une formation. L'anesthésiologie présente des avantages et des inconvénients ; réduire ces derniers et accentuer les premiers, devrait permettre de trouver encore beaucoup plus de satisfaction à la pratiquer.
\end{abstract}

\section{Les inconvénients de la pratique de l'anesthésie}

\section{A L'espérance de vie des anesthésiologistes}

Il y a eu des discussions interminables au fil des ans à propos de l'effet de l'environnement de la salle d'opération sur la longévité des anesthésiologistes qui y travaillent. En 1968, une enquête rétrospective sur la cause de décès parmi les anesthésiologistes américains a trouvé que le taux de mortalité était plus faible que celui de la population mâle générale, comme l'était le taux de mortalité lié à tout cancer. Cependant, il y avait une augmentation statistique significative de l'incidence de cancer des systèmes lymphoïde et réticulo-endothélial. Une deuxième étude prospective ${ }^{2}$ n'a pu confirmer cette incidence de cancer, tandis qu'une troisième étude $^{3}$ n'a pas montré d'évidence d'une hausse due au cancer ou à des maladies hépatiques et rénales.

$\mathrm{La}$ théorie selon laquelle l'environnement anesthésique serait hypothétiquement carcinogène comporte la contamination par d'infimes quantités de médicaments anesthésiques. Toutefois, on n'a jamais pu prouver d'incidence accrue de cancer chez des animaux soumis à des expositions prolongées de faibles concentrations d'anesthésiques. De plus, aucun effet mutagène n'a été observé lors des tests habituels in pitro de recherche d'agents cancérogènes pendant des études sur les anesthésiques volatils. Néanmoins, une façon pratique et logique de réduire les risques consiste à se débarrasser de tout matériel étranger et des gaz expirés.
La mort en service et la retraite anticipée d̀ cause d'une mauvaise santé ont augmenté de façon significative chez les anesthésistes consultants en Angleterre comparés à des consultants témoins de cinq autres spécialités médicales. ${ }^{4}$ Malheureusement, les données de cette étude sont confidentielles et nous ne connaissons pas les causes de décès ou la nature des problèmes de santé qui ont conduit à une retraite anticipée.

Le suicide est souvent rapporté dans la profession médicale et chez les anesthésiologistes en particulier. ${ }^{3}$ Une étude plus récente, au R-U, n'indique pas de risque plus grand chez les anesthésistes, mais confirme l'augmentation de risques chez les médecins pris comme groupe comparé à la population générale. ${ }^{5}$ L'âge n'était pas un facteur de risque en soi, mais on était très préoccupé par le nombre de suicides chez les stagiaires en anesthésie. Ce qui représentait probablement le problème grandissant de la toxicomanie dans ce groupe.

\section{$B$ Risques pour la reproduction}

Il y a quelques années, des études épidémiologiques ont fait craindre que l'exposition à des concentrations très faibles de gaz anesthésiques soit reliée à une augmentation du risque d'avortement spontané et de malformations congénitales possibles à la naissance. Tandis qu'on pouvait reprocher à la plupart de ces études le choix de leur modèle et de leurs groupes mis en comparaison, l'évidence la plus convaincante est venue des chirurgiens-dentistes. À la suite des réponses à un important questionnaire rétrospectif distribué aux dentistes et à leurs assistants, on a suggéré que les gens qui travaillent dans des bureaux où ils sont exposés à du protoxyde d'azote courent davantage de risques de problèmes de santé que ceux qui n'y sont pas exposés. ${ }^{6}$ Les femmes qui travaillent dans ces endroits présentaient une incidence d'avortement spontané 2,3 fois plus élevée que celles du groupe témoin. Une autre enquête ${ }^{7}$ avance que les assistantes dentaires exposées au protoxyde d'azote ont une fertilité réduite.

Cependant, ces enquêtes questionnaires sont très sujettes à des biais de la part des répondants. En outre, 
on a montré que le risque accru d'avortement n'est pas limité aux femmes qui administrent des anesthésiques. Une enquête scandinave ${ }^{8}$ rapporte un taux d'avortement de $21 \%$ chez les infirmières instrumentistes, de 17 $\%$ chez celles de l'USI et de $15 \%$ chez celles de l'anesthésie. Enfin, une étude plus objective, utilisant des fichiers informatisés du Swedish Health Registry (bureau de santé suédois) ${ }^{9}$, qui passait en revue les dossiers obstétriques de travailleuses en salle d'opération et les comparait à ceux de femmes d'autres départements médicaux, ne montre pas de différence intergroupe quant à l'incidence de menace d'avortement, de taux de mortalité, de poids des enfants à la naissance ou de malformations congénitales.

Spence $^{10}$ a mené une enquête de 1977 à 1984 auprès de toutes les diplômées d'une école de médecine, âgées de 40 ans ou moins et travaillant dans un hôpital du R-U. Les données portaient sur la profession, les conditions de travail, le style de vie, l'histoire médicale et obstétricale et quelques détails personnels. On a récolté $85-92 \%$ de réponses parmi 11500 femmes interrogées. L'enquête a montré que les femmes anesthésiologistes ne présentaient pas de risque accru d'infertilité, et qu'il n'y avait pas de corrélation entre l'avortement spontané ou le développement de malformations congénitales chez les nouveau-nés et le travail de la mère, les heures d'exposition à la salle d'opération ou l'emploi d'appareils d'aspiration. Il n'y avait pas non plus d'incidence plus élevée de cancer ou de neuropathie.

On doit en conclure que la possibilité d'un avortement spontané est le seul problème médical significatif, potentiel, du personnel féminin de la salle d'opération, mais même ce risque est très faible (moins que pour les fumeuses ou les femmes en radiologie). La cause du problème, si elle existe, n'est pas évidente.

\section{La sensibilisation au latex}

Dans les dernières années, l'application de mesures de prévention généralisées contre la transmission de maladies infectieuses a provoqué un autre sujet d'inquiétude, l'allergie au latex. La sensibilisation des travailleurs de la santé peut conduire à de sévères réactions allergiques au latex, incluant la mort par anaphylaxie (réaction de type I). L'exposition pendant le travail génère des immunoglobulines IgE vers les protéines des produits de caoutchouc naturel; exposé de nouveau aux allergènes, en qualité de patient, l'individu risque d'avoir une réaction mortelle. Plus de 15 cas semblables nnt été raninnrtéc d̀ la FDA entre 1088 er 100) On: mente le risque de sensibilisation de $8 \%$ qu'il est dans la population générale, à $20 \%$ !

Il est à noter que l'allergène aéroporté compte pour 80-90\% des expositions de la plupart des travailleurs de la santé, provenant surtout du fait de mettre et d'enlever les gants enduits de poudre. ${ }^{11}$ Les concentrations d'allergène sur les gants varient énormément, de plus de 3000 fois parmi les manufacturiers. Avec un même produit, on peut multiplier les variations par 40 d'un lot à l'autre, d'une même marque. Les autres voies d'exposition sont nombreuses, comprenant le contact dermique direct, l'absorption par la peau abrasée ou l'exposition cutanéo-muqueuse. On a même rapporté une exposition indirecte chez des familles à partir d'un contact avec les protéines provenant du brossage chirurgical du personnel médical!

Les individus les plus à risque sont ceux qui ont une histoire d'atopie et de dermatite des mains et qui utilisent souvent des gants jetables. Une étude de prévalence menée auprès de médecins torontois ${ }^{12}$ a été récemment confirmée aux É- $\mathrm{U}^{13}$ et a montré que des symptômes reliés au port de gants n'ont pas révélé de façon fiable une allergie au latex lors de test cutané.

Réciproquement, l'absence de symptômes reliés aux gants n'exclut pas la sensibilisation! Les symptômes de la sensibilisation sont non spécifiques et rappellent ceux d'une infection des voies respiratoires supérieures (larmoiement, rougeur, gonflement des paupières, congestion nasale, éternuements, respiration sifflante, etc.), douleurs gastro-intestinales ou éruption non spécifique, prurit ou sensations de brûlure des mains. Le seul indice pourrait être en relation avec les heures de travail.

La solution logique est donc de STOPPER LA SENSIBILISATION! Le personnel de la salle d'opération devrait utiliser des gants, non poudrés, de latex faible en allergène, des gants synthétiques ou de vinyle. De plus, la peau intacte constituant une barrière efficace, il faut utiliser des lotions à base d'eau et couvrir les coupures et les plaies ouvertes avec du sparadrap.

\section{$D$ Maladies infectieuses}

La première ligne de défense contre l'infection comporte l'usạge régulier de barrières protectrices : gants, blouse et visière. Il faut enlever des gants contaminés avant de toucher d'autres patients, des seringues d'anesthésique ou d'autres articles (un stylo qui sert à compléter le dossier!). Hélas, les précautions universelles ne sont pas universellement appliquées. Une

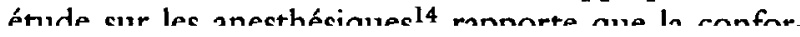


était seulement de $55 \%$, comprenant un faible $11 \%$ pour les professeurs de plus de 55 ans.

L'infection cutanée par le sang est liée à $18 \%$ des piqûres de veines périphériques, $87 \%$ des veines centrales et $38 \%$ des insertions artérielles. Les gants peuvent réduire la contamination de $98 \%$. Les plaies par pénétration, surtout avec des aiguilles creuses, étant les plus dangereuses pour la transmission de maladies, il est bon de savoir que l'incidence de piqûre d'aiguille n'augmente pas avec le port de gants. ${ }^{15}$ Dans une étude prospective multicentrique des lésions percutanées chez le personnel d'anesthésie ${ }^{16}, 87 \%$ provenaient des pointes de sonde creuses, $43 \%$ étaient modérées ou profondes et $68 \%$ auraient été évitées avec de meilleures techniques.

\section{Prévention CONTRe Le viRus DU SYNDROME IMMUNODÉFICITAIRE ACQUIS (VIH)}

Quoiqu'ayant reçu la plus grande presse, le risque estimé d'infection au VIH à la suite d'une exposition percutanée à du sang ou à des liquides corporels n'est que de $0,3 \%$. Les facteurs de risque de séroconversion comprennent des plaies profondes, une contamination manifeste avec le sang du patient porteur, des techniques par lesquelles l'appareil contaminant a été placé dans une veine ou une artère du patient infecté et une maladie terminale du patient porteur. ${ }^{17}$

Malgré le faible risque d'infection après une seule exposition, la prévalence de la maladie dans la population $(0,3 \%$ de tous les sujets aux É-U, mais plus élevée chez les traumatisés), les inévitables piqûres d'aiguilles accidentelles et le nombre d'années de pratique, le risque de contracter le SIDA pour un jeune anesthésiologiste, pendant une carrière de plus de 40 ans, peut être aussi élevé que $1 / 25$ !

La gestion des risques chez les sujets exposés a changé récemment au R-U, au Canada ${ }^{18}$ et aux É-U. Essentiellement, il est maintenant souhaitable de commencer une triple chimioprophylaxie immédiatement (entre $\mathbf{l}$ et $\mathbf{2} \mathrm{h}$ après l'exposition, si possible) dans les situations à haut risque. Il est possible que les médicaments n'agissent pas si leur administration subit un délai de 24-36 h. ${ }^{17}$

II Contamination par le virus de l'HÉpatite B Opposé au bas taux de séroconversion noté après l'exposition au VIH, le risque d'infection après une piqûre d'aiguille contaminée avec l'antigène $\mathrm{e}$ associé au virus de l'hépatite B est de $37 \%$. La prévalence du virus dans la population chirurgicale est aussi plus importante que celle du VIH, allant de 0,2 à $1,51 \%$. La séroprévalence du VHB correspond davantage à la fréquence de contact avec le sang contaminé; la fréquence des accidents avec les aiguilles a un effet indépendant mais moindre. La prévention se fait par immunisation avec le vaccin de l'hépatite $\mathrm{B}$.

\section{EXPOSITION AU VIRUS DE L'HÉpatite C}

Le risque d'infection par la piqûre d'une aiguille qui a été en contact avec du sang contaminé par le VHC est d'environ $2 \%$, taux établi lors d'un contrôle d'accident du travail relié à la dialyse. Mais ce ne sont pas tous les patients qui présentent une antigénémie $\mathrm{HCs}$ positive, faisant en sorte que le test n'est pas utile pour déterminer l'état de porteur ou d'infection chronique.

Il n'y a pas de vaccin contre le VHC; la seule prévention possible repose sur les précautions d'emploi générales du sang. La prophylaxie immunoglobuline n'est plus recommandée après une exposition percutanée au VHC.

\section{Tuberculose multirésistante}

La prévalence de la TB augmente régulièrement en Amérique du Nord depuis 1985, de même la résistance aux médicaments : $33 \%$ des nouveaux cas à New York seraient résistants à l'isoniazide. La transmission de la tuberculose prenant la forme de fines gouttelettes dans l'air, nous risquons d'être infectés par des patients atteints de maladies pulmonaires actives. ${ }^{19}$

Concernant la prévention en milieu de travail, il faut mentionner que les masques habituellement portés en salle d'opération ne sont pas assez étanches pour filtrer les organismes infectieux; des masques spéciaux d'efficacité supérieure et offrant de meilleures qualités de filtration ou des respirateurs personnels étanches pourraient être nécessaires. Une surveillance régulière des travailleurs de la santé par un test cutané annuel est aussi recommandée. Le vaccin BCG n'est pas rentable comparé au test régulier à la tuberculine et à la thérapie préventive.

\section{E Maladie reliée au stress}

Le stress professionnel a été défini comme «une perception négative qui, en tant que résultat d'une adaptation problématique aux sources de stress, a des conséquences négatives sur la santé mentale ou physique. ${ }^{20}$ Le stress relève de l'interdépendance de l'individu et de son environnement et survient quand il y a une perception de déséquilibre entre les demandes faites à l'individu et son habileté à les satisfaire. Même s'il est inévitable dans notre vie personnelle et professionnelle et que des niveaux modérés de stress nous fournissent l'énergie nécessaire pour agir efficacement, c'est au moment où on en perd le contrôle que les problèmes commencent. 
L'Association des anesthésistes de Grande-Bretagne et d'Irlande a dirigé une session interactive en septembre 1995 et a proposé une certaine mesure du problème. Les principales sources de stress seraient le manque de contrôle ( $42 \%$ des répondants), les responsabilités administratives (41\%) et les conflits entre les exigences professionnelles et familiales (35\%).

Le stress n'est pas réservé aux anesthésiologistes; lors d'une enquête menée par l'AMC en 1998 auprès des médecins canadiens, la majorité a rapporté des sentiments de frustration et de la fatigue. ${ }^{21}$ Les anesthésiologistes soulignaient, en particulier, l'impossibilité d'organiser leur propre vie professionnelle. ${ }^{22} \grave{A}$ 40 ou 50 ans on s'attend à pouvoir organiser et contrôler son plan de travail, mais l'incapacité à le faire contribue au stress.

Une récente étude américaine sur le vieillissement et le stress en anesthésie ${ }^{23}$ a montré qu'à tout âge les appels de nuit sont très stressants et que c'est la raison majeure de prendre sa retraite. Tandis que les jeunes médecins attribuent davantage de stress à l'incertitude économique, à la pression de produire et à des difficultés de relations interpersonnelles, les médecins du groupe de 40-49 ans affirment que la question des responsabilités est la plus stressante.

L'influence du manque de sommeil et de la fatigue sur la performance des médecins en général et des anesthésiologistes en particulier, a reçu une attention spéciale. ${ }^{24}$ Les résident en sont plus affectés; une récente enquête nationale auprès de résidents américains a montré que le sommeil n'était pas suffisant pour maintenir une activité optimale. ${ }^{25}$ Cela pourrait expliquer l'incidence deux fois plus élevée que la normale d'accidents d'automobile impliquant des résidents en anesthésie après les heures de garde. ${ }^{26}$

\section{Maladies PHycholoqiQues}

La dépression, le désenchantement et l'insatisfaction sont répandus chez les médecins et peu d'indices laissent croire que les anesthésiologistes en souffrent plus que d'autres médecins en milieu hospitalier, en centre communautaire ou en pratique générale. En mai 1998, le Medical Post a cité le directeur du BC College of Physicians and Surgeons selon lequel $\ll 10 \%$ des médecins de la province avaient subi des examens pour une incapacité reliée au stress»! Ce sujet d'inquiétude a mené à une nouvelle entité psychiatrique ("thérapeute blessé») et à la publication par l'AMC d'un résumé de politique sur la santé et le bien-être des médecins. ${ }^{27}$

Concernant l'anesthésie, la plupart des études publiées sont extrêmement dépassées en regard de la pratique moderne. Une enquête canadienne menée en
1988 auprès des anesthésiologistes cadres supérieurs ${ }^{28}$ de l'Alberta et de l'Ontario a montré qu'ils étaient très satisfaits de leur travail; les moins satisfaits étaient, en moyenne, plus jeunes de sept ans par rapport au groupe satisfait. Les médecins étudiés ont été qualifiés d'«intelligents, quelque peu dominants mais sensibles, indépendants tout en manquant un peu d'assurance et plutôt tendus. Ils étaient aussi tolérants, timides, et plutôt sérieux. Les femmes étaient plus émotives, sensibles et surprotectrices." Toutefois, il n'y a pas d'étude parallèle auprès de membres d'autres spécialités!

Une récente enquête américaine ${ }^{29}$ a mis en corrélation le stress professionnel des anesthésiologistes et le nombre d'heures passées en salle d'opération. De plus, les individus très stressés sont plus susceptibles de dépression, de fatigue, de colère et d'irritabilité, ainsi que de céphalées et d'hostilité. Une fois de plus, il n'y avait pas de groupe témoin d'autres spécialistes.

L'alcoolisme serait plus fréquent chez les médecins par rapport à d'autres groupes, mais il est difficile de le prouver. Les anesthésiologistes ne semblent pas particulièrement à risque.

L'usage de drogues illégales (marijuana et cocaïne) était plus courant chez les internes et les résidents canadiens que dans la population générale. Cependant, comparés à un groupe témoin du même âge, il n'y a pas de différence; les résultats reflètent simplement les moeurs sociales d'un groupe âge. Malheureusement, les stagiaires d'anesthésiologie et de psychiatrie étaient de plus grands utilisateurs que ceux d'autres spécialités. Une enquête menée dans une grande école américain $e^{30}$ n'a montré aucune différence dans l'usage de psychotropes par les diplômés de médecine interne (19,9\%), de chirurgie $(14,4 \%)$ ou d'anesthésie $(16,8 \%)$.

\section{Chimiodependance}

On sait maintenant que l'abus de substances chimiques représente une maladie professionnelle majeure pour les anesthésiologistes. ${ }^{31}$ Basée sur les données d'une enquête de la ASA portant sur la toxicomanie, l'incidence d'abus de nouvelles drogues (parmi toutes les drogues) pendant l'année de formation 1994-95 était de 0,4\% pour les résidents et de $0,1 \%$ pour les praticiens. Le cas particulier d'abus de fentanyl par les résidents était de $0,25 \%$ pendant cette même année. Ce qui est, en fait, un déclin au cours de l'enquête qui a duré 10 ans. Cette enquête a montré aussi un taux de récidive, chez les médecins qui reviennent à la pratique de l'anesthésiologie, de $19 \%$ $(6 / 31)$ chez les résidents et de $5 \%(1 / 20)$ chez les praticiens.

La chimiodépendance chez les médecins est une maladie de la solitude, du désespoir, de la culpabilité 
grandissante et de la peur. Ce n'est pas une toxicomanie «sociale» comme celle de la marijuana, de la cocaine ou d'autres drogues consommées dans d'autres milieux. Les anesthésiologistes ne forment que $4 \%$ des médecins, mais jusqu'à $30 \%$ des médecins des centres de soins aux toxicomanes; est-ce un phénomène de détection ou une véritable différence d'incidence, on ne saurait le dire. Les facteurs favorisants comprennent le stress du travail, l'isolation, le manque de reconnaissance et d'estime de soi. Bien sûr, il y a toujours la possibilité que la spécialité attire ceux qui ont une personnalité sensible et que, combiné à l'accès quotidien aux drogues, ce soit un facteur à considérer.

\section{LA RÉDUCTION DES RISQUES DE MALADIES} LIÉES AU STRESS

La réduction du stress passe d'abord par la reconnaissance de son existence chez nous et les autres et du besoin de considérer avec un esprit ouvert les facteurs responsables dans la vie quotidienne. Chacun doit simplifier son existence par des défis à sa mesure : limiter le nombre de choses qu'on possède, les activités auxquelles on s'est lié ou qu'on s'est engagé à mener à terme. Le succès acquis au dépend de la joie de vivre n'est plus un succès!

Les anesthésiologistes doivent apprendre à gérer efficacement les facteurs de stress et découvrir d'importantes habiletés de communication, d'affirmation de soi, de règlement des conflits et de gestion du temps. En étant bien informés de ce qui se passe dans nos hôpitaux et en y prenant part, les médecins éprouvent moins de frustration quand des changements surviennent. Enfin, nous devons éviter d'adopter une conduite irrationnelle, comme de procéder à une anesthésie tout en sachant qu'on se trompe, parce que le chirurgien nous presse de le faire.

\section{Les avantages de la pratique de l'anesthésiologie}

\section{A Perspectives d'emploi}

Beaucoup de changements sont survenus pendant les dernières années dans la façon de prodiguer les soins médicaux et dans le mode de rémunération. Nous avons adopté une vision conservatrice quant au recrutement du personnel, laissant des postes vacants plutôt que de risquer d'être trop nombreux avec une quantité de travail réduite. Ce qui a laissé croire qu'il n'y avait plus de travail pour les diplômés et qu'on ne devait plus s'inscrire à des études d'anesthésiologie.

Une analyse de la situation canadienne à partir du CaRMS (Canadian Resident Matching Service) de 1996 ne permet pas de dire que les diplômés des écoles de médecine canadiennes considèrent déjà le marché du travail, le salaire potentiel ou le prestige dont jouit la profession lorsqu'ils choisissent une carrière. Les raisons évoquées pour avoir choisi l'anesthésiologie étaient : faire un stage dans la spécialité (84 $\%$ ), avoir de l'intérêt pour ce champ de pratique à part $(78 \%)$ et s'identifier à quelqu'un de la profession (75 $\%)$. La présence de modèles inspirants dans la communauté des anesthésiologistes, observée par les étudiants qui font des stages dans différents départements, a été particulièrement remarquable. Une enquête antérieure, de 1993, indique les attraits de l'anesthésiologie par les termes : «expérience pratique directe», "temps libre», "physiologie / pharmacologie» et "gratification immédiate». ${ }^{32}$ Il est clair que si nous voulons recruter, il faut éloigner des étudiants tous ceux qui discréditent la spécialité!

En réalité, le travail ne manquera pas au Canada. À la réduction du nombre des résidents imposée par les régulations gouvernementales s'ajoutent les obstacles à l'immigration et à l'expansion de notre rôle périopératoire, ce qui nous privera de praticiens pour des années encore.

\section{$B$ Qualité de vie}

Nous sommes nombreux à reconnaitre le fait que la pratique de l'anesthésiologie peut accorder une des meilleures qualités de vie personnelle conjuguée à une carrière professionnelle. Les heures régulières de travail, le tour de garde prévisible, les occasions nombreuses de partage du travail ou de pratique réduite et la possibilité d'avoir des intérêts en dehors de la profession attirent beaucoup de candidats. À l'évidence, ces «intérêts hors profession» contribuent à donner de l'anesthésiologie l'image intéressante d'une carrière médicale équilibrée.

Un avantage supplémentaire découle de la responsabilité de base en anesthésiologie : plutôt que d'être «sur appel» direct du patient comme c'est le cas dans le domaine des soins primaires, l'anesthésiologiste répond aux besoins de l'institution médicale. Les appels sont toujours fondés et prévisibles; les anesthésiologistes qui ne sont «pas de garde» sont rarement appelés au travail. Peu ou pas de spécialités présentent un tel avantage!

\section{Qualité de la pratique}

Toutes les tâches répétitives deviennent monotones avec le temps; la pratique de l'anesthésie n'y échappe pas. Cependant, l'anesthésiologie est l'une des spécialités de soutien dites «horizontales» qui nous met en contact avec des patients de presque tous les autres médecins. Nous participons à tous les services médicaux : à la salle d'opération, à l'USI, en radiologie, à la cli- 
nique ou en obstétrique. Peu de spécialités présentent aussi cet avantage; la plupart ont une organisation «verticale» qui limite leur contact avec les patients selon les caractéristiques de ce dernier (pédiatrie, obstétrique, etc.) ou selon le système organique (ophtalmologie, orthopédie, urologie, etc.). Le contact avec le plus grand nombre de patients et le plus grand nombre de pathologies, gardera notre intérêt pour les progrès médicaux et la satisfaction de notre rôle de soutien.

\section{Rémunération}

Ce qui est regrettable dans la récente réforme des soins de santé, c'est l'impact financier sur les praticiens autonomes. Avant 1993, les départements d'anesthésiologie étaient ceux qui rapportaient le plus aux hôpitaux et aux écoles de médecine et la rémunération augmentait progressivement. Mais depuis, le contrôle des dépenses de santé aux É-U et la réforme hospitalière au Canada ont retourné la situation. Les institutions ont appris que «les soins bon marché ne sont pas des soins", mais que, quand il faut en donner, c'est au meilleur prix. En fait, l'anesthésiologie est passée de l'actif au passif en un temps remarquablement court!

$A u x \quad \dot{E}-U$, la Medical Group Management Association suit les données financières de diverses spécialités. Les données de base en anesthésiologie sont de 1347 membres en pratique privée et de 1183 de plus en milieu universitaire. Le revenu calculé selon les honoraires bruts moyens pour 1997 a été publié en 1998 :

\section{Honoraires bruts moyens pour 1997 (E-U)}

\begin{tabular}{|c|c|c|}
\hline Spécialité & $\begin{array}{l}\text { Pratique } \\
\text { privée }\end{array}$ & $\begin{array}{l}\text { Milieu } \\
\text { unipersitai }\end{array}$ \\
\hline Anesthésiologie & & \\
\hline ine familiale & 13243 & $00 \$$ \\
\hline ine interne & $00 \$$ & $72 \$$ \\
\hline ie & $39 \$$ & $105846 \$$ \\
\hline Médecine d'urgence & $179997 \$$ & $148737 \$$ \\
\hline Chirurgie générale & $223388 \$$ & $198135 \$$ \\
\hline Chirurgie orthopédique & $310475 \$$ & 246113 \\
\hline
\end{tabular}

Au Canada, nous n'avons pas à négocier les contrats des médecins de la même manière, alors nos données sont un peu en retard. Cependant, l'AMC utilise les données de l'Institut canadien d'information sur la santé (ICIS), qui sont basées sur la facturation reçue par les régimes d'assurance maladie provinciaux, pour déterminer les honoraires à l'acte (HAA) moyens par médecin. Ces montants sont corrigés pour fournir des moyennes équivalentes à un travail à temps complet (ETC) et ils sont présentés généralement par spé- cialité. ${ }^{33}$ Les montants bruts facturés peuvent être corrigés en soustrayant le \% des frais généraux estimés par l'AMC à partir des renseignements d'enquête.

Moyenne des HAA des médecins pour des ETC (Canada)

$\begin{array}{ll}\text { Groupe } & \text { Moyens bruts \% des frais Nets estimés } \\ 1993-94 & \text { (avant taxes) }\end{array}$

$\begin{array}{lrrl}\text { Anesthésie } & 172353 \$ & 17 \% & 143053 \$ \\ \text { Médecine familiale } & 157044 \$ 39 \% & 95483 \$ \\ \text { Spéc. médicales } & 170915 \$ & 29 \% & 121521 \$ \\ \text { Spéc. chirurgicales } & 228673 \$ & 36 \% & 144979 \$ \\ \text { Tous } & 173095 \$ & 36 \% & 110608 \$\end{array}$

Rappelons que les données de l'ICIS ne comprennent pas les honoraires payés par salaire, capitation, vacation ou autre formule de rémunération. Le fait que l'AMC rapproche les montants d'un ETC tente de compenser cette omission qui, autrement, ferait baisser les honoraires des spécialités où cette forme de paiement est fréquente.

Si les spécialistes gagnent encore davantage que leurs confrères des soins primaires, ils travaillent aussi davantage. Et si les salaires diminuent encore, en raison de compressions, restructurations ou récupérations, ils travailleront davantage et de façon plus réfléchie. Les anesthésiologistes peuvent difficilement agir ainsi, indépendamment des autres membres de la salle d'opération, ce qui laisse peu de chances de compenser les transformations du financement des soins de santé. Reste plus qu'une solution, réduire le personnel et, individuellement, fournir plus d'heures de travail pour maintenir leur revenu. Tandis que cette réduction semblait convenir au début des années 1990, les résultats d'une enquête de la SCA montrent que la plupart des anesthésiologistes canadiens sont débordés et que la quantité de travail contribue à l'instabilité actuelle.

\section{Conclusion}

Les anesthésiologistes (et d'autres médecins) se sentent peut-être victimes de la réorganisation récente des services médicaux, étant qualifiés maintenant comme membres du «secteur des services», contribuant au bon fonctionnement des soins de santé. Le passage de médecin individuel à «membre d'un programme» est déjà commencé, et nous en recueillons les bénéfices par des rôles plus étendus, en médecine périopératoire et ambulatoire par exemple. L'examen de l'évolution et de l'efficacité des soins nous conduit à considérer les anesthésiologistes (et d'autres médecins) comme des participants à un cheminement ou à un programme 
plutôt que des professionnels dénigrés ou des praticiens individuels. Ce n'est peut-être pas le rôle que nous avions envisagé au moment de choisir notre carrière, mais nous serons à l'avenir des collaborateurs respectés et nécessaires à l'avancement des soins de santé.

Tout bien considéré, l'examen des avantages et des inconvénients d'une carrière en anesthésiologie nous donne raison d'être optimistes. Les inconvénients physiques et psychologiques que nous subissons peuvent être facilement réduits par des mesures simples; les avantages peuvent être durables. Malheureusement, les temps changent et les changements entraînent inévitablement de l'insécurité. Cependant, puisque. l'homme n'est pas touché «par les choses, mais par.sa perception des choses», il est temps de prendre la spécialité du bon côté!

\section{Reférences}

(Voir page Rl36) 